\title{
Analisis Kesulitan Siswa Berdasarkan Kemampuan Pemahaman Konsep Matematis dalam Menyelesaikan Soal Materi SPLDV
}

\author{
Nurindah $^{1}$, Nita Hidayati ${ }^{2}$ \\ 1,2 Program Studi Pendidikan Matematika, Fakultas Keguruan dan Ilmu Pendidikan, Universitas Singaperbangsa, \\ Jl. HS. Ronggo Waluyo, Puseurjaya, Kec. Telukjambe Tim., Kabupaten Karawang, Indonesia \\ nur.indah17020@student.unsika.ac.id
}

\begin{abstract}
The pupose of this study was to determine the difficualties of student in solving math problems in terms of understanding the concept Mathematical in Secondary VIII (Eighth) Junior High school in the material of the Two Variable Linear Equation System. This type of research uses descriptive research with a qualitative approach. The subjects of this study consisted of 3 students with lowest mathematical concepts' ability. The result of this study stated that there are student difficultes in solving SPLDV questions based on their ability to understand mathematical conceps. This could be seen from the results of an average score of $58 \%$ and it is tncluded in the less category. As for the diffuculties that are experienced by students, namely: they haven't understood what is being asked on the question, the difficulties in applying the concept of algorithmic solution, and choosing an operation in solving the algebraic from.
\end{abstract}

Keywords: student difficulties, solve the problem, understanding of mathematical concept

\begin{abstract}
Abstrak
Fokus dalam penelitian ini yaitu bagaimanakah kesulitan siswa dalam menyelesaikan soal matematika ditinjau dari pemahaman konsep matematis siswa kelas VIII SMP pada materi Sistem Persamaan Linear Dua Variabel (SPLDV). Jenis penelitian ini menggunakan penelitian deskriptif dengan pendekatan kualitatif. Subjek pada penelitian ini berjumlah 3 orang siswa dengaan hasil tes kemampuan pemahaman konsep matematis terendah. Hasil yang diperoleh dari penelitian menyatakan bahwa terdapat kesulitan siswa dalam menyelesaikan soal SPLDV berdasarkan pada kemampuan pemahaman konsep matematis. Hal ini dapat kita lihat dari hasil skor rata-rata yaitu sebesar 58\% dan termasuk kedalam kategori kurang. Adapun kesulitan yang dialami siswa yaitu: belum memahami apa yang ditanyakan dalam soal, kesulitan dalam mengubah suatu permasalahan menjadi kalimat matematika atau model matematika, siswa kurang mampu dalam mengelompokkan objek yang diketahui dalam soal, kesulitan dalam menerapkan konsep penyelesaian secara algoritma dan memilih operasi dalam menyelesaikan bentuk aljabar.
\end{abstract}

Kata kunci: Kesulitan siswa, Menyelesaikan soal, Pemahaman konsep matematis

Copyright (c) 2021 Nurindah, Nita Hidayati

$\triangle$ Corresponding author: Nurindah

Email Address: nur.indah17020@ student.unsika.ac.id (Jl. HS.Ronggo Waluyo, Puseurjaya, Karawang)

Received 10 August 2021, Accepted 09 September 2021, Published 14 December 2021

\section{PENDAHULUAN}

Suatu bangsa dapat dikatakan maju tentu dilihat dari sumber daya manusianya tetapi bukan dilihat dari jumlahnya melainkan dilihat dari seberapa baik kualitas sumber daya itu sendiri. Di zaman seperti sekarang ini, sangat dibutuhkan sumber daya manusia yang berdaya saing sehingga keberadaannya mampu ditempatkan dalam situasi dan kondisi sesuai dengan perkembangan zaman. Untuk menjadi sumber daya manusia yang berdaya saing dibutuhkan peran dan usaha dari berbagai pihak terutama dari dirinya sendiri. Salah satu usaha untuk meningkatkan kualitas diri sendiri adalah melalui pendidikan. Wiyasa, Komang Ngurah, I Wayan Wiarta (2017) menyatakan bahwa pendidikan merupakan suatu kebutuhan yang sangat penting bagi manusia dimana keberadaannya berfungsi untuk meningkatkan mutu kehidupan manusia, menyelesaikan dan mengembangkan sumber daya manusia yang handal yang dimana tujuan pendidikan itu sendiri yaitu menciptakan sumber daya 
manusia yang berdaya saing. Melalui pedidikan manusia memperoleh ilmu pengetahuan dan mampu menggali potensi yang terdapat pada dirinya yang nantinya dapat digunakan untuk bersaing dengan negara lain dalam berbagai bidang.

Pada setiap jenjang pendidikan formal tidak pernah terlepas dari mata pelajaran matematika baik pada jenjang pendidikan yang paling dasar hingga perguruan tinggi matematika tetap ada dan dipelajari, hal ini membuktikan bahwa matematika merupakan ilmu penting yang harus dipelajari. Carl Friedrich Gauss (Wahyudi et al., 2018) menyatakan bahwa matematika adalah ratu dan pelayan ilmu (mathematics is the queen and servant of science). Matematika sebagai ratunya ilmu artinya bahwa matematika sebagai sumber dari ilmu lain dan pada perkembangannya tidak tergantung pada ilmu lain sedangkan matematika sebagai pelayan maksudnya yaitu bahwa matematika merupakan ilmu yang mendasari dan melayani berbagai ilmu pengetahuan lainnya maka tidak heran jika matematika muncul dalam berbagai ilmu pengetahuan lainnya seperti kimia, fisika, astronomi dan lain sebagainya. Matematika juga merupakan ilmu yang memaksa siswanya untuk berkembang hal ini dapat dilihat dari perbedaan tingkat kesulitan pada soal yang guru berikan baik soal pada contoh, soal pada latihan maupun soal pada ulangan memiliki tingkat kesulitan yang berbeda.

Matematika merupakan suatu kebutuhan guna untuk menyelesaikan permasalahan dalam kehidupan sehari-hari, misalnya dalam mengoprasikan perhitungan seperti penjumlahan, pengurangan, perkalian, pembagian maupun mengaplikasikan konsep matematika. Maka dari itu, matematika merupakan ilmu yang penting untuk dipelajari meskipun pada kenyataannya masih banyak siswa yang mengganggap matematika tidak penting dan dalam proses pembelajarannya dianggap terlalu rumit dan membosankan sehingga kebanyakan siswa lebih memilih untuk menghindari matematika daripada mempelajarinya. Sebagaimana yang dikemukakan oleh Abdurahman (Sholekah et al., 2017) dari berbagai mata pelajaran yang diajarkan diajarkan di sekolah, matematika merupakan mata pelajaran yang dianggap paling sulit oleh siswa, baik bagi siswa yang tidak kesulitan dalam belajar terlebih bagi siswa yang kesulitan dalam belajar. Kesulitan siswa dalam mempelajari matematika dapat dilihat dari hasil belajar siswa yang masih tergolong rendah

Adapun tujuan mata pelajaran matematika untuk semua jenjang pendidikan dasar dan menengah menurut Kamarullah (2017) adalah sebagai berikut: (1) Memahami konsep matematika, menjelaskan keterkaitan antarkonsep dan mengaplikasikan konsep atau algoritma secara luwes, akurat, efesien dan tepat dalam pemecahan masalah; (2) Menggunakan penalaran pada pola dan sifat, melakukan manipulasi matematika dalam membuat generalisasi, menyusun bukti atau menjelaskan gagasan dan pernyataan matematika; (3) Memecahkan masalah yang meliputi kemampuan memahami masalah, merancang model matematika, menyelesaikan model dan menafsirkan solusi yang diperoleh; (4) Mengkomunikasikan gagasan dengan symbol, tabel, diagram atau media lain untuk memperjelas keadaan atau masalah; (5) Memiliki sikap menghargai kegunaan matematika dalam kehidupan, yaitu rasa ingin tau, perhatian, dan minat dalam mempelajari matematika, serta sikap ulet dan percaya diri dalam pemecahan masalah. 
Hasil pengamatan dan wawancara dengan guru matematika di salah satu sekolah menengah pertama (SMP) Negeri di kabupaten Cirebon peserta didik sering kali mengalami kesulitan dalam menyelesaikan soal-soal matematika. Kesulitan yang dihadapi siswa dalam menyelesaikan soal-soal matematika yaitu siswa masih kesulitan dalam memilih dan menggunakan algoritma penyelesaian matematika yang harus digunakan, siswa masih kesulitan dalam melakukan operasi dalam menyelesaikan suatu permasalahan matematika. Hal ini disebabkan karena siswa masih belum memahami kosep suatu materi, baik materi sebelumnya maupun materi yang sedang dipelajari. Termasuk pada materi Sistem Persamaan Linear Dua Variabel (SPLDV), Materi SPLDV bagi peserta didik SMP merupakan materi yang baru dipelajari maka dari itu peserta didik perlu mengingat materi sebelumnya dan memahami konsep pada materi SPLDV itu sendiri. Hal yang perlu dilakukan untuk menguasai materi SPLDV bukan hanya mengandalkan kemampuan menghafal rumus karena pada materi SPLDV tidak terdapat rumus maka dari itu hal yang perlu dilakukan untuk menguasai materi SPLDV adalah memahami konsep dan aturan-aturan yang terdapat pada materi SPLDV. Pemilihan materi SPLDV yaitu karena banyak peserta didik yang kesulitaan dalam mempelajari materi SPLDV bahkan beberapa diantaranya tidak tertarik untuk mempelajari materi SPLDV.

Siswa dikatakan memiliki kemampuan pemahaman konsep matematika jika dan hanya jika dia dapat merumuskan strategi penyelesaian, menerapkan perhitungan sederhana, menggunakan simbol untuk mempresentasikan konsep dan mengubah suatu bentuk ke bentuk lain seperti pecahan dalam pembelajaran matematika (Kartika, 2018). Adapun Indikator pemahaman konsep matematis menurut Adapun Indikator pemahaman konsep matematis menurut Wardhani (Mawaddah \& Maryanti, 2016) yaitu a) Menyatakan ulang sebuah konsep; b) Mengklasifikasikan objek menurut sifat-sifat tertentu sesuai dengan konsepnya; c) Memberi contoh dan bukan contoh dari suatu konsep; d) Menyajikan konsep dalam berbagai bentuk representasi matematis; e) Mengembangkan syarat perlu dan syarat cukup dari suatu konsep; f) Menggunakan dan memanfaatkan serta memilih prosedur atau operasi tertentu; g) Mengaplikasikan konsep atau algoritma pada pemecahan masalah.

Berdasarkan uraian di atas, peneliti tertarik untuk melakukan penelitian tentang Analisis Kesulitan Siswa dalam Menyelesaikan Soal Matematika Ditinjau Dari Pemahaman Konsep Matematis pada materi sistem persamaan linear dua variabel (SPLDV). Penelitian ini dilakukan untuk mengetahui kesulitan siswa dalam menyelesaikan soal matematika ditinjau dari kemampuan pemahaman konsep matematis diharapkan hasil dari penelitian ini dapat menjadi gambaran dan acuan untuk Pengajar dalam melakukan pembelajaran yang lebih baik sehingga nantinya dapat meminimasilir tingkat kesulitan siswa dalam menyelesaikan permasalahan matematika khususnya pada materi SPLDV.

\section{METODE}

Penelitian ini menggunakan penelitian deskriptif dengan pendekatan kualitatif. Menurut Sugiyono (2015) metode penelitian kualitatif adalah suatu metode yang berlandaskan pada filsafat 
postpositifisme yang dilakukan pada kondisi objek yang alamiah, dimana dalam penelitian kualitatif yang bekerja sebagai instrumen kunci yaitu peneliti itu sendiri. Sasaran penelitian yaitu siswa kelas VIII SMP/MTs sederajat sebanyak 10 orang dan subjek penelitian diambil sebanyak 3 siswa dengan skor terendah. Adapun penskoran tes pemahaman konsep matematis siswa menurut Agustini \& Pujiastuti (2020) sebagai berikut:

Tabel 1. Rubrik Penskoran Pemahaman Konsep Matematis Siswa

\begin{tabular}{|c|l|}
\hline Skor & \multicolumn{1}{|c|}{ Sajian jawaban } \\
\hline 4 & $\begin{array}{l}\text { Konsep dan prinsip terhadap soal matematika secara lengkap, penggunaan istilah dan } \\
\text { notasi secara tepat, penggunaan algoritma secara lengkap dan benar }\end{array}$ \\
\hline 3 & $\begin{array}{l}\text { Konsep dan prinsip terhadap soal matematika hampir lengkap, penggunaan istilah dan } \\
\text { notasi hampir benar, perhitungan secara umum benar namun mengandung sedikit } \\
\text { kesalahan }\end{array}$ \\
\hline 2 & $\begin{array}{l}\text { Konsep dan prinsip terhadap soal matematika kurang lengkap, jawaban mengandung } \\
\text { perhitungan yang salah }\end{array}$ \\
\hline 1 & $\begin{array}{l}\text { Konsep dan prinsip terhadap soal matematika sangat terbatas, jawaban sebagian besar } \\
\text { belum lengkap dan mengandung perhitungan yang salah }\end{array}$ \\
\hline 0 & Tidak menunjukkan pemahaman konsep dan prinsip terhadap soal matematika \\
\hline
\end{tabular}

Teknik pengumpulan data yang digunakanberupa tes dan wawancara. Tes yang digunakan berupa soal yang terkait materi Sistem persamaan linear dua variabel (SPLDV), tes digunakan untuk memperoleh data siswa dalam menyelesaikan soal pemahaman konsep, wawancara dilakukan untuk menggali informasi secara mendalam tentang kesulitan siswa ketika mengerjakan soal tersebut. Siswa yang akan diwawancarai adalah siswa yang melakukan jenis kesalahan yang dianggap menarik untuk diteliti pada beberapa item soal berdasarkan materi SPLDV.Teknik analisis data yang digunakan adalah menurut Sugiyono (2015) yaitu reduksi data, penyajian data, dan menarik kesimpulan. Analisis tes yang dilakukan dengan menggunakan rumus sebagai berikut:

$$
S=\frac{\text { skor yang diperoleh siswa }}{\text { skor maksimal }} \times 100 \%
$$

Adapun skor kemampuan pemahaman konsep matematis siswa mengacu pada pendapat Huda (Agustini \& Pujiastuti, 2020).

Tabel 2. Skor Kemampuan Pemahaman Konsep Matematis Siswa

\begin{tabular}{|c|l|}
\hline Nilai & \multicolumn{1}{c|}{ Kriteria } \\
\hline $86-100$ & Sangat Baik \\
\hline $76-85$ & Baik \\
\hline $60-75$ & Cukup \\
\hline $55-59$ & Rendah \\
\hline Kurang dari 54 & Sangat Rendah \\
\hline
\end{tabular}

\section{HASIL DAN DISKUSI}

Penelitian ini dilaksanakan di kelas VIII SMP/ MTs sederajat dengan jumlah siswa 10 siswa kemudian akan dilakukan wawancara pada 3 siswa dengan skor terendah. Tahap pertama siswa 
diberikan tes tertulis terlebih dahulu. Tes yang digunakan dalam penelitian ini merupakan hasil adopsi dari instrumen tes yang digunakan oleh Fawi Jarmi dalam penelitinnya yang berjudul "Kemampuan Pemahaman Konsep Melalui Penerapan Pendekatan Problem Possing Pada Peserta Didik SMP” (2020).

Peneliti memberikan instrumen tes materi SPLDV (Sistem Persamaan Linear Dua Variabel) berdasarkan indikator pemahaman konsep matematis, sebagai berikut:

1. Jelaskan apa yang kamu ketahui tentang SPLDV!

2. Pilihlah persamaan - persamaan di bawah ini yang bukan merupakan PLDV!
a. $\quad x+y=6$
b. $\quad 2 x+3 x=8$
c. $3 p=2 q+3$
d. $\quad 4 a-5 b=10$
e. $x^{2}+y^{2}=8$
f. $\quad 3 a=4 a-7$

3. Seorang pedagang buah - buahan mendapatkan uang sebesar Rp 50.000 dari menjual 6 mangga dan 10 jeruk, sedangkan dari menjual 8 mangga dan 4 jeruk ia mendapat uang sebesar Rp 48.000. Jika ia menjual 20 mangga dan 30 jeruk, banyak uang yang ia peroleh adalah...

4. Pada suatu pagi, Ibu Ani dan Ibu Rani berbelanja di pasar pagi, Ibu Ani membeli $2 \mathrm{~kg}$ gula dan $2 \mathrm{~kg}$ tepung dengan membayar seharga Rp 38.000,00. Sedangkan Ibu Rani membeli $1 \mathrm{~kg}$ gula dan $3 \mathrm{~kg}$ tepung dengan membayar seharga Rp 43.000. Berapakah harga $1 \mathrm{~kg}$ gula dan $1 \mathrm{~kg}$ tepung?

Berikut ini adalah tabel hasil tes kemampuan pemahaman konsep matematis siswa yang telah dilakukan oleh siswa kelas VIII sebanyak 10 orang.

Tabel 2. Hasil Tes Kemampuan Pemahaman Konsep Matematis Siswa

\begin{tabular}{|c|c|c|l|}
\hline No & Subjek Penelitian & Skor (dalam persen) & Kategori \\
\hline 1 & SK 1 & 50 & Sangat kurang \\
\hline 2 & SK 2 & 66 & Cukup \\
\hline 3 & SK 3 & 43 & Sangat kurang \\
\hline 4 & SK 4 & 62 & Cukup \\
\hline 5 & SK 5 & 58 & Kurang \\
\hline 6 & SK 6 & 56 & Kurang \\
\hline 7 & SK 7 & 81 & Baik \\
\hline 8 & SK 8 & 33 & Sangat kurang \\
\hline 9 & SK 9 & 55 & Kurang \\
\hline 10 & SK 10 & 48 & Sangat Kurang \\
\hline Jumlah rata-rata & $\mathbf{5 8}$ & Kurang \\
\hline
\end{tabular}

Berdasarkan tabel 2, terdapat 1 orang siswa yang mendapatkan skor dengan kategori baik, 2 orang siswa dengan kategori cukup, 3 orang siswa dengan kategori kurang dan 4 orang siswa dengan 
kategori sangat kurang. Skor rata-rata hasil tes kemampuan pemahaman konsep matematis siswa pada materi SPLDV yaitu 58\%, sehingga termasuk kedalam kategori kurang. Tahap selanjutnya yaitu wawancara, berdasarkan tabel 2 siswa yang dipilih untuk menjadi subjek penelitian untuk dianalsisis kesulitannya dan diwawancarai yaitu subjek dengan kategori sangat kurang yaitu SK1(Siswa Ke-1), SK3 (Siswa Ke-3) dan SK8 (Siswa Ke-8). Berikut ini dipaparkan hasil jawaban siswa pada tes pemahaman konsep matematis siswa dan hasil wawancara siswa berdasarkan indikator pemahaman konsep matematis:

\section{Menyatakan Ulang Sebuah Konsep}

Soal nomor 1: Jelaskan apa yang kamu ketahui tentang SPLDV!

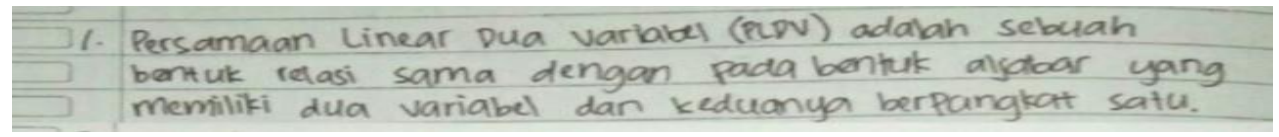

Gambar 1. Jawaban Siswa SK1 Soal 1

Berdasarkan gambar diatas, SK1 sudah mampu menyatakan ulang konsep PLDV tetapi yang ditanyakan dalam soal adalah siswa diperintahkan untuk mendefinisikan pengertian dari SPLDV, hal ini menunjukkan bahwa pertama SK1 tidak teliti dalam membaca soal, kedua SK1 belum memahami konsep PLDV berbeda dengan konsep SPLDV.

Berdasarkan hasil wawancara, SK1 tidak teliti atau ceroboh dalam membaca soal dikarenakan siswa terburu-buru dalam mengerjakan soal tersebut. Hal ini sejalan dengan penelitian Ananda menyatakan bahwa kesalahan konsep dilakukan sebanyak 33,33\% dari jawaban keseluruhan, kesalahan ini dilakukan karena siswa belum memahami dengan baik apa yang ditanyakan dalam soal sehingga dalam menyelesaikannya menjadi salah (Ananda et al., 2018). Kemudian berdasarkan pernyataan SK1 terlihat bahwa siswa belum memahami konsep SPLDV, SK1 menganggap bahwa SPLDV dan PLDV merupakan hal yang sama. Maka dapat disimpulkan bahwa SK1 belum memahami konsep SPLDV.

\section{Memberi Contoh dan Bukan Contoh dari Suatu Konsep}

Soal Nomor 2: Pilihlah persamaan-persamaan di bawah ini yang bukan merupakan PLDV!
a. $x+y=6$
b. $2 x+3 x=8$
c. $3 p=2 q+3$
d. $4 a-5 b=10$
e. $x^{2}+y^{2}=8$
f. $3 a=4 a-7$

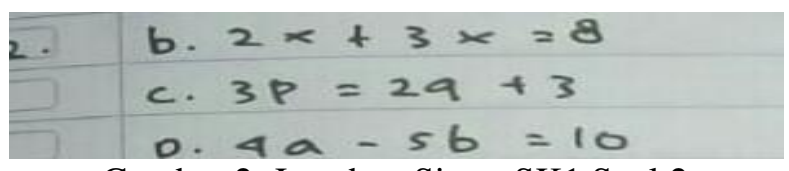

Gambar 2. Jawaban Siswa SK1 Soal 2 
Berdasarkan gambar diatas, SK1 belum mampu untuk membedakan mana yang termasuk PLDV dan mana yang bukan sehingga jawaban pada nomor dua masih salah. Hal ini disebabkan karena SK1 belum mamahami konsep dan ciri-ciri dari PLDV. Berdasarkan hasil wawancara, SK1 kebingungan dalam membedakan mana yang PLDV dan mana yang bukan PLDV, hal ini dikarenakan SK1 belum betul-betul memahami ciri-ciri dari PLDV dan SK1 masih belum memahami dengan benar bagaimana bentuk umum dari PLDV. Maka dapat disimpulkan bahwa SK1 belum mampu memberikan contoh dan bukan contoh dari suatu konsep.

\section{Menyajikan Konsep dalam Berbagai Bentuk Representasi Matematis}

Soal nomor 3: Seorang pedagang buah - buahan mendapatkan uang sebesar Rp 50.000 dari menjual 6 mangga dan 10 jeruk, sedangkan dari menjual 8 mangga dan 4 jeruk ia mendapat uang sebesar Rp 48.000. Jika ia menjual 20 mangga dan 30 jeruk, banyak uang yang ia peroleh adalah...

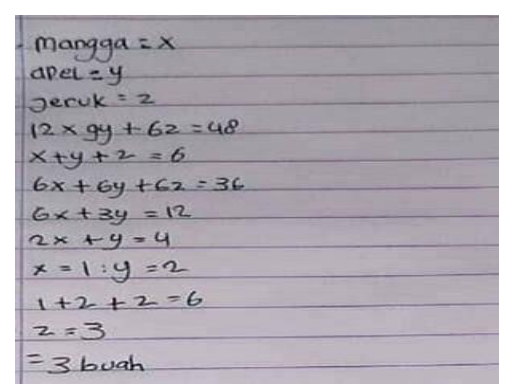

Gambar 3. Jawaban Siswa SK8 Soal 3

Berdasarkan gambar diatas, SK8 masih kesulitan dalam membuat kalimat matematika dari permasalahan yang diberikan. Dimana SK8 menambahkan salah satu variabel lagi yaitu apel, seharusnya $6 x+10 y=50.000$ tetapi SK8 menuliskan $12 x+9 y+6 z=48$. Berdasarkan hasil wawancara, SK8 menyatakan bahwa dalam membuat kalimat matematika siswa melakukannya dengan asal-asalan hal ini disebabkan karena SK8 masih belum mengerti bagaimana membuat kalimat matematika dari suatu permasalahan diperparah dengan siswa tidak menuliskan informasi penting yang terdapat dalam soal. Maka dapat disimpulkan SK8 masih kesulitan dalam menyajikan konsep matematika dalam bentuk representasi lainnya. Hal ini sejalan dengan Kurniawan yang mengungkapkan bahwa sebagian besar siswa masih kurang mampu menuliskan apa yang diketahui dan apa yang ditanyakan dalam soal (Kurniawan et al., 2019).

\section{Mengembangkan Syarat Perlu dan Syarat Cukup Dari Suatu Konsep}

Soal nomor 4: Pada suatu pagi, Ibu Ani dan Ibu Rani berbelanja di pasar pagi, Ibu Ani membeli 2 kg gula dan 2 kg tepung dengan membayar seharga Rp 38.000,00. Sedangkan Ibu Rani membeli $1 \mathrm{~kg}$ gula dan $3 \mathrm{~kg}$ tepung dengan membayar seharga Rp 43.000. Berapakah harga $1 \mathrm{~kg}$ gula dan $1 \mathrm{~kg}$ tepung? 


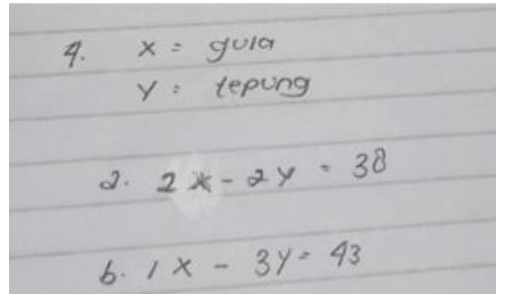

Gambar 4. Jawaban Siswa SK3 Soal 4

Berdasarkan gambar diatas, SK3 sudah mampu membuat kalimat matematika dari soal yang diberikan tetapi SK3 masih keliru dalam memberikan tanda tambah (+) atau kurang (-). Yang seharusnya ditambah tetapi SK3 menuliskannya dengan tanda kurang, kita ketahui bahwa hal ini keliru. Hal ini menunjukkan bahwa SK3 tidak teliti dalam membaca soal atau memang SK3 tidak memahami bagaimana cara membuat kalimat matematika dari suatu permasalahan. Pada gambar diatas SK3 tidak mencari solusi untuk menyelesaikan soal tersebut. Hal ini menunjukkan bahwa SK3 belum memahami cara untuk menyelesaikan permasalahan tersebut. Berdasarkan hasil wawancara, SK3 belum memahami bagaimana cara membuat kalimat matematika dari suatu permasalahan kemudian SK3 juga belum memahami metode-metode untuk menyelesaikan SPLDV. Maka dapat disimpulkan bahwa SK3 kesulitan dalam menentukan syarat cukup dari suatu konsep dan belum memahami metode-metode dalam menyelesaikan SPLDV. Sejalan dengan pendapat Yanti et al., (2019) yang menyatakan bahwa kelemahan pemahaman konsep siswa belum bisa mengembangkan syarat perlu atau syarat cukup suatu konsep dengan tepat, serta keliru dalam memahami soal.

\section{Menggunakan dan Memanfaatkan Serta Memilih Prosedur atau Operasi Tertentu}

Soal nomor 3: Seorang pedagang buah - buahan mendapatkan uang sebesar Rp 50.000 dari menjual 6 mangga dan 10 jeruk, sedangkan dari menjual 8 mangga dan 4 jeruk ia mendapat uang sebesar Rp 48.000. Jika ia menjual 20 mangga dan 30 jeruk, banyak uang yang ia peroleh adalah

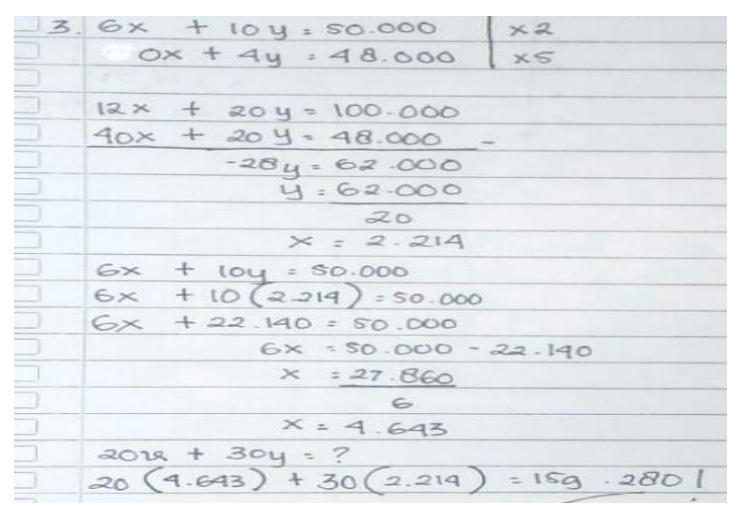

Gambar 5. Jawaban Siswa SK1 Soal 3

Berdasarkan gambar diatas, SK1 sudah mampu membuat kalimat matematika dari suatu permasalahan dengan benar. Tetapi SK1 masih kesulitan dalam mengembangkan konsep metode eliminasi dan SK1 tidak memahami konsep dari metode eliminasi yang seharusnya ketika sebuah persamaan dikalikan dengan suatu angka maka semua anggota pada persamaan tersebut dikalikan dengan angka tersebut, hal ini terlihat dari dalam persamaan 2 terdapat 48.000 namun setelah 
persamaan 2 dikali 5, anggota dari persamaan 2 dikalikan 5 namun 48.000 tidak dikali 5 hal ini menyebabkan hasil akhir dari penyelesaian tersebut keliru. Berdasarkan hasil wawancara, SK1 memahami konsep eliminasi dengan baik. Namun SK1 melakukan kecerobohan yaitu tidak mengalikan 48.000 dengan 5. Maka dapat disimpulkan bahwa SK1 masih kesulitan dalam menerapkan prosedur atau operasi dalam metode eliminasi sehingga menyebabkan hasil dari penyelesaian tersebut masih keliru. Sejalan dengan Hikmah et al., (2019) yang menyatakan bahwa siswa berkemampuan rendah mengalami kesulitan dari aspek kemampuan prasyarat atau pemahaman tentang materi sebelumnya. Akibatnya siswa mengalami kesulitan dalam menyelesaikan operasi aljabar pada metode eliminasi.

\section{Mengaplikasikan Konsep atau Algoritma pada Pemecahan Masalah}

Soal nomor 4: Pada suatu pagi, Ibu Ani dan Ibu Rani berbelanja di pasar pagi, Ibu Ani membeli $2 \mathrm{~kg}$ gula dan 2 kg tepung dengan membayar seharga Rp 38.000,00. Sedangkan Ibu Rani membeli $1 \mathrm{~kg}$ gula dan $3 \mathrm{~kg}$ tepung dengan membayar seharga Rp 43.000. Berapakah harga $1 \mathrm{~kg}$ gula dan $1 \mathrm{~kg}$ tepung?

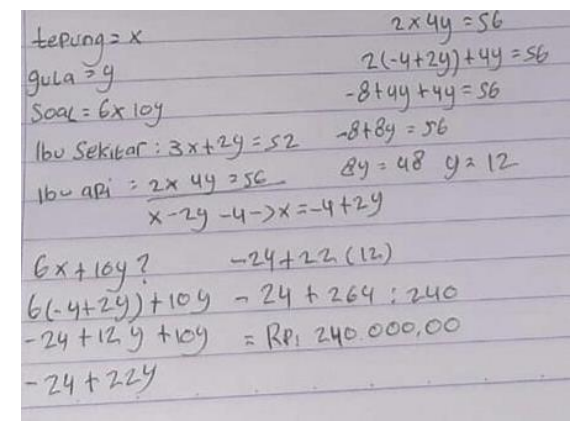

Gambar 6. Jawaban Siswa SK8 Soal 4

Berdasarkan gambar diatas, SK8 belum mampu mengubah permasalahan menjadi kalimat matematika dengan benar. Kemudian SK8 masih kesulitan dalam menggunakan metode dalam penyelesaian SPLDV tersebut. SK8 dalam menggunakan metode eliminasi masih keliru dimana seharusnya ketika kedua persamaan tersebut dieliminasi akan menghasilkan satu variabel saja tetapi dalam perhitungan SK8 dengan menggunakan metode eliminasi masih menyisakan 2 variabel. Hal ini terjadi karena SK8 masih belum paham syarat untuk melakukan eliminasi dari SPLDV adalah harus menghilangkan salah satu variabelnya dengan cara menyamakan koefisien dari variabel yang akan dihilangkan. Berdasarkan hasil wawancara, SK8 masih kesulitan dalam menggunakan metode eliminasi hal ini disebabkan karena SK8 memiliki pemahaman yang salah mengenai metode eliminasi. Hal ini sejalan dengan Annisa \& Kartini (2021) yang menyatakan bahwa siswa keliru jika tidak mampu merancang rumus yang sesuai.

\section{KESIMPULAN}

Berdasarkan hasil penelitian yang telah dilakukan, dapat disimpulkan bahwa terdapat kesulitan pada siswa dalam menyelesaikan soal pada materi SPLDV berdasarkan kemampuan pemahaman 
konsep matematis. Hal ini terlihat dari hasil skor rata-rata yaitu sebesar 58\% yang termasuk kedalam kategori kurang. Adapun macam-macam kesulitan yang dialami siswa yaitu: belum memahami apa yang ditanyakan dalam soal, masih kesulitan dalam mengubah suatu permasalahan menjadi kalimat matematika atau model matematika, siswa kurang mampu dalam mengelompokkan objek yang diketahui dalam soal, masih kesulitan dalam menerapkan konsep penyelesaian secara algoritma dan memilih operasi dalam. menyelesaikan bentuk aljabar.

\section{UCAPAN TERIMA KASIH}

Puji syukur kehadirat Allah swt. Karena berkat rahmat dan karunia-Nya peneliti dapat menyelesaikan artikel ini. Ucapan terimakasih disampaikan kepada semua pihak yang telah membantu dalam proses penyusunan artikel ini. Peneliti juga berterimakasih kepada orang tua yang selalu mendukung dan mendoakan peneliti, kepada dosen pembimbing yang selalu memberikan motivasi dan arahan sehingga peneliti dapat menyelesaikan artikel ini.

\section{REFERENSI}

Agustini, D., \& Pujiastuti, H. (2020). Analisis Kesulitan Siswa Berdasarkan Kemampuan Pemahaman Matematis dalam Menyelesaikan Soal Cerita pada Materi SPLDV. Media Pendidikan Matematika, 8(1), 18. https://doi.org/10.33394/mpm.v8i1.2568

Ananda, R. P., Sanapiah, S., \& Yulianti, S. (2018). Analisis Kesalahan Siswa Kelas VII SMPN 7 Mataram dalam Menyelesaikan Soal Garis dan Sudut Tahun Pelajaran 2018/2019. Media Pendidikan Matematika, 6(2), 79. https://doi.org/10.33394/mpm.v6i2.1838

Annisa, R., \& Kartini, K. (2021). Analisis Kesalahan Siswa dalam Menyelesaikan Soal Barisan dan Deret Aritmatika Menggunakan Tahapan Kesalahan Newman. Jurnal Cendekia: Jurnal Pendidikan Matematika, 5(1), 522-532. https://doi.org/10.31004/cendekia.v5i1.506

Hikmah, A., Roza, Y., \& Maimunah, M. (2019). Analisis Kemampuan Komunikasi Matematis Siswa

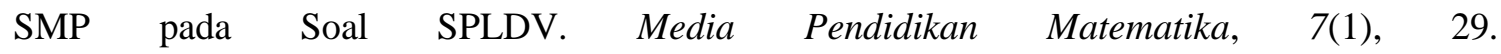
https://doi.org/10.33394/mpm.v7i1.1428

Jarmi, F. (2020). Kemampuan Pemahaman Konsep Melalui Penerapan Pendekatan Problem Possing pada Peserta Didik SMP. Human Relations, 3(1), 1-8.

Kamarullah, K. (2017). Pendidikan Matematika di Sekolah Kita. Al Khawarizmi: Jurnal Pendidikan dan Pembelajaran Matematika, 1(1), 21. https://doi.org/10.22373/jppm.v1i1.1729

Kartika, Y. (2018). Analisis Kemampuan Pemahaman Konsep Matematis Peserta Didik Kelas VII SMP pada Materi Bentuk Aljabar. Jurnal Pendidikan Tambusai, 2(2), 777-785.

Kurniawan, A., Juliangkary, E., \& Pratama, M. Y. (2019). Analisis Kesulitan Siswa dalam Menyelesaikan Soal Fungsi. Media Pendidikan Matematika, $7(1), \quad 72$. https://doi.org/10.33394/mpm.v7i1.1679

Mawaddah, S., \& Maryanti, R. (2016). Kemampuan Pemahaman Konsep Matematis Siswa SMP 
dalam Pembelajaran Menggunakan Model Penemuan Terbimbing (Discovery Learning). EDUMAT: Jurnal Pendidikan Matematika, 4(1), 76-85. https://doi.org/10.20527/edumat.v4i1.2292

Sholekah, L. M., Anggreini, D., \& Waluyo, A. (2017). Analisis Kesulitan Siswa dalam Menyelesaikan Soal Matematika Ditinjau dari Koneksi Matematis Materi Limit Fungsi. WACANA AKADEMIKA: Majalah Ilmiah Kependidikan, 1(2), 151-164. https://doi.org/10.30738/wa.v1i2.1413

Wahyudi, Suyitno, H., \& Waluya, S. B. (2018). Dampak Perubahan Paradigma Baru Matematika Terhadap Kurikulum dan Pembelajaran Matematika di Indonesia. Jurnal Ilmiah Kependidikan, $1(1), 38-47$.

Wiyasa, Komang Ngurah, I Wayan Wiarta, N. L. N. D. (2017). Model Pembelajaran Kooperatif Tipe Scramble Berbantuan Bahan Manipulatif Pengetahuan Matematika. 1, 133-140.

Yanti, N., Sofiyan, Ramadhani, D., \& Putra, dan A. (2019). Analisis Pemahaman Konsep Matematika Siswa pada Materi Skala Kelas V SD Negeri 2 Langsa Tahun Pelajaran 2019/2019. Journal of Basic Education Studies, 2(2), 90-102. http://jurnal.unipasby.ac.id/index.php/buana_matematika/article/view/2442. 